\title{
PRAKTIK PENADAHAN HASIL PENCURIAN SEPEDA MOTOR DI KABUPATEN BIMA
}

\author{
Hajairin \\ Sekolah Tinggi Ilmu Hukum (STIH) Muhammadiyah Bima, Kota Bima, 84116, Indonesia \\ (hajairinbima@yahoo.com)
}

\begin{abstract}
Abstrak, Praktik penadahan terhadap hasil pencurian sepeda motor di Kabupaten Bima, dapat di kategorikan dalam penadahan dan pencurian, dalam tindak pidana penadahan diatur dalam Pasal 480 KUHP sedangkan tindak pidana pencurian diatur dalam Pasal 362 KUHP, selain itu banyak orang yang menggunakan sepeda motor curian sehingga memudahkan siapa pun untuk mencuri sepeda motor, karena pencuri tidak mengalami kesulitan dalam menjual produk curiannya, sedangkan penadahan terhadap hasil pencurian sepeda motor adalah kejahatan dilakukan oleh pihak ketiga sebagai tuan rumah, dengan maksud mendapatkan manfaat dari hasil pencurian sepeda motor yang dilakukan oleh orang lain. Kejahatan pencurian sepeda motor di Kabupaten Bima, muncul sebagai masalah sosial baru, kolektor tidak hanya mengumpulkan, menyimpang hasil pencurian sepeda motor di daerah setempat di Kabupaten Bima saja, tetapi juga dapat menerima pencurian sepeda motor dan penggelapan sepeda motor. di daerah lain seperti Pulau Lombok, Jawa dan Jakarta dll. Dinamika ini menjelaskan adanya kejahatan struktural dalam pencurian sepeda motor di Kabupaten Bima, struktural dapat menjadi pencegahan di Kabupaten Bima bekerja sama dengan kolektor di luar Kabupaten Bima untuk memfasilitasi penyimpangan dari hasil pencurian sepeda motor.
\end{abstract}

\section{Kata Kunci : Praktik, Penadahan Hasil Pencurian Motor}

Abstract, The practice of deterrence of the results of motorcycle theft in Bima Regency, actually there are different criminal acts, namely criminal detention and theft, in the criminal offense is regulated in Article 480 of the Criminal Code (KUHP) while criminal acts of theft are set in Article 362 of the Criminal Code (KUHP), besides that many people use stolen motorbikes also make it easy for anyone to steal motorbikes, because thieves have no difficulty in selling their stolen products, whereas deterrence of the results of motorcycle theft is a crime committed by a third party as a host, with the intention of benefiting from the results of motorcycle theft committed by another person. The crime of motorcycle theft in the Regency of Bima, appears as a new social problem, collectors not only collect, deviating the results of motorcycle theft in the local area in the district of Bima only, but also can receive motorbike theft and embezzlement of motorbikes in other areas such as the island of Lombok, Java and Jakarta etc. This dynamic explains the existence of structural crimes in motorcycle theft in Bima Regency, the structural can be deterrence in Bima Regency in collaboration with collectors outside Bima Regency to facilitate the deviation of the results of the motorcycle theft.

\section{Keywords : Motorcycle Retaining Practices}

\section{A. PENDAHULUAN}

Dalam praktik penadahan hasil pencurian sepeda motor di Kabupaten Bima, sebetulnya sudah menjadi bagian dari kebutuhan dari kehidupan sehari-hari masyarakat Bima, sehingga secara umum implikasinya adalah masyarakat di pedesaan banyak menggunakan motor hasil dari pencurian kepada seorang penadah 
tersebut. Sebab penadahan adalah yang dapat menampung hasil pencurian sepeda motor, sehingga selain masyarakat banyak menggunakan motor hasil curian juga memberikan kemudahan bagi siapapun untuk melakukan pencurian sepeda motor, sebab pencuri tidak mendapatkan kesulitan dalam menjual hasil curianya. Padahal penadahan hasil pencurian sepeda motor merupakan kejahatan yang dilakukan oleh pihak ketiga sebagai penadah, dengan maksud mendapatkan keuntungan dari hasil pencurian sepeda motor yang dilakukan oleh orang lain. Penadahan adalah tindakan atau menampung, menyimpang, dan lain sebagainya barang-barang hasil kejahatan, umumnya hasil kejahatan pencurian. ${ }^{1}$

Dengan adanya orang yang berperan sebagai orang ketiga dalam kejahatan pencurian sepeda motor di Kabupaten Bima tersebut, muncul sebagai masalah sosial baru, penadah tidak hanya mengumpulkan, menyimpang hasil pencurian sepeda motor dalam wilayah lokal di kabupaten bima saja, tetapi juga dapat menerima sepeda motor hasil pencurian dan penggelapan sepeda motor di Daerah lain seperti pulau Lombok, pulau Jawa dan Jakarta, Dll hal ini dibuktikan banyaknya kendaraan sepeda motor yang mempunyai nomor polisi di luar area Kota Dan Kabupaten Bima, juga dapat dilihat dari praktik jual-beli sepeda motor yang hanya mempunyai surat STNK Saja, dan hal itu sudah biasa dipraktikan di Kabupaten Bima, berdasarkan hasil dalam penelitian ini.

Dinamika ini menjelaskan adanya kejahatan secara struktural dalam pencurian sepeda motor di Kabupaten Bima, struktural tersebut bisa penadahan di Kabupaten Bima bekerja sama dengan penadah di luar Kabupaten Bima untuk melancarkan penyimpangan hasil pencurian sepeda motor tersebut. Selain itu adanya penadah di Kabupaten Bima ini membuat pencuri sepeda motor dapat melakukan aksinya dalam mencuri sepeda motor tersebut sesuai

1. Muhammad Ali, 2002, Kamus Lengkap Bahasa Indonesia Modern, Jakarta, Pustaka Aman, Hal 479 dengan kebutuhan seseorang yang ingin membeli sepeda motor melalui seorang penadah yang selalui berkomunikasi dengan siapapun yang ingin membeli motor yang ingin dicurinya barulah pencuri mencuri motor yang dibutuhkan.

Apabila dilihat dalam aspek hukum pidana penadahan itu merupakan suatu delik pemudahan, karena dengan adanya seseorang sebagai penadah dapat memudahkan orang dalam di mendistribusikan sepeda motor hasil curian si pelaku kepada penadah yang berperan sebagai orang ketiga tersebut. Dalam ketentuan Pasal 480 Kitab Undang-Undang Hukum Pidana (KUHP) menyebutkan pada Ayat (1) menyebutkan Barangsiapa membeli, menyewa, menukar, menerima gadai, menerima hadiah, atau untuk menarik keuntungan, menjual, menyewakan, menukarkan, menggadaikan, mengangkut, menyimpan atau menyembunyikan sesuatu benda, yang diketahui atau sepatutnya harus diduga bahwa diperoleh dari kejahatan penadahan dan Ayat (2) Barangsiapa menarik keuntungan dari hasil sesuatu benda, yang diketahuinya atau sepatutnya harus diduga bahwa diperoleh dari kejahatan.

Sebenarnya Pada rumusan Pasal 480 KUHP di atas menggambarkan adanya unsur yang disebut sebagai tindak pidana dalam penadahan sebab setiap orang yang mendapatkan suatu barang baik melalui membeli, menyewa, menukar, menerima gadai, menerima hadiah atau untuk menarik keuntungan, menjual barang itu, menyewakan barang itu, menukarkan barang itu, menggadaikan barang itu, mengangkut barang itu, menyimpan barang itu atau menyembunyikan barang itu yang seharusnya diketahui atau sepatutnya diduga bahwa diperoleh dari suatu tindak kejahatan, dengan demikian dalam posisi yang tergambarkan tersebut dapat dikenakan Pasal mengenai Penadahan.

Sehingga barang siapa menarik keuntungan dari hasil suatu benda yang diketahuinya atausepatutnya dapat diduga 
bahwa diperoleh dari kejahatan. ${ }^{2}$ sedangkan Tindak Pidana Pencuriandiatur di dalam Pasal 362 KUHP yang berbunyi Barangsiapa mengambil suatu barang, yang seluruhnya atau sebagian kepunyaan orang lain, dengan maksud untuk memilikinya secara melawan hukum, diancam karena pencurian dengan pidana penjara paling lama lima tahun atau denda sebanyak-banyaknya Rp 900.000.

Namun selain itu apabila tindakan seseorang memenuhi unsur-unsur pencurian di Pasal 362 KUHP maka orang tersebut dapat dikenakan ancaman pidana yang dimaksud. Unsur-unsur Barangsiapa mengambil suatu barang, yang seluruhnya atau sebagian kepunyaan orang lain dan Dengan maksud untuk memilikinya secara melawan hukum. lebih lanjut mengenai pencurian juga tersebar dalam beberapa Pasal misalnya KUHP Pasal 363ayat (1) Barangsiapa mengambil barang sesuatu, yang seluruhnya atau sebagian kepunyaan orang lain dengan maksud untuk dimiliki secara melawan hukum, di ancam karena pencurian, dengan pidana penjara paling lama lima tahun atau denda paling banyak enam puluh ribu rupiah"

Selanjutnya KUHP Pasal 365(1) Diancam dengan pidana penjara paling lama 9 (sembilan) tahun, pencurian yang didahului, disertai atau diikuti dengan kekerasan atau ancaman kekerasan, terhadap orang, dengan maksud untuk mempersiapkan atau mempermudah pencurian, atau dalam hal tertangkap tangan, untuk memungkinkan melarikan diri sendiri atau peserta lainnya, atau untuk tetap menguasai barang yang dicuri.(2) Diancam dengan pidana penjara paling lama 12 (dua belas) tahun:

Dalam pengamatan peneliti praktik penadahan hasil pencurian sepeda motor di Kabupaten Bima marak terjadi, hal ini sebenarnya disebabkan oleh kultur masyarakat bima yang tidak mau ambil repot dan wajah penegakan hukkum dalam berlalu lintas masih bisa di kompromi pada

2 . Redaksi Bhafana Fublishing, 2014,KUHP KUHAP, Jakarta: Bhafana Publishing, Hal 140 akhirnya membeli motor yang tidak lengkap, akibat tingginya permintaan masyarakat, maka membuat pencuri dapat mengkomunikasi barang hasil curianya untuk dapat di jual oleh pihak ketiga yang disebut penadah.

Pencurian kendaraan bermotormerupakan kejahatan terhadap harta benda yang tidak lazim terjadi dinegara-negara berkembang. Sebagaimana dikatehui kendaraanbermotor merupakan sarana transportasidengan mobilitas yang tinggi. ${ }^{3}$ Seiring banyaknya kasus pencurian kendaraanbermotor, maka semakin banyak pulatindak pidana penadahan kendaraan bermotor hasil dari pencurian tersebut.

Namun apabila kita temukan tindak pidana Penadahan dan tindak pidana Pencurian merupakan delik yang berbeda atau terpisah sendiri yang diatur dalam pasal-pasal yang berbeda pula, unsur-unsur tindak pidananya pun berbeda jadi walaupun tindak pidana penadahan sepeda motor tersebut pencurinya belum diketahui berkas perkara dapat dinyatakan lengkap oleh Penuntut Umum terkait penadahannya. Memang ada baiknya pencurinya diketahui untuk mempermudah pembuktian dalam pemeriksaan di pengadilan walaupun hal tersebut tidak mutlak.

Berdasarkan temuan di lapangan bahwa kasus penadahan di Kabupaten Bima cukup tinggisehingga praktik penadahan hasil pencurian sepeda motor yang di anggap tinggi pada Kabupaten Bima, harus segera di anggap sebagai masalah yang besar, dan segera juga di temukan solusinya agar dapat lakukan pembersihan terhadap praktik penadahan yang semakin merajalela yang saat ini semakin merajalela.

Di balik kasus kejahatan yang berhubungan dengan barang, ada imbas yangmenyeret orang-orang tertentu karena diduga sebagai penadah. Bisa karena orangorang tertentutersebut membeli, menjual, membawa, menyimpan, mgadaikan, menerima gadai, atau sekedarmenawarkan

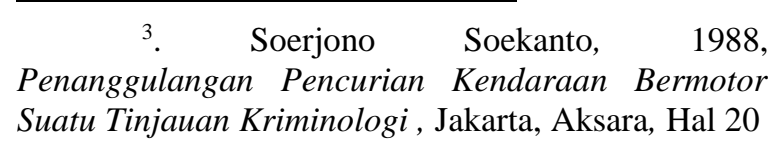


barang yang diduga kuat merupakan hasil dari tindak kejahatan, sehingga di butuhkan peran banyak pihak dalam meminimalisir terjadi praktik penadahan hasil pencurian sepeda motor di Kabupaten Bima.

Berdasarkan latar belakang masalah diatas Sehingga Fokus penelitian ini adalah pada pemetaan Praktik Penadahan Hasil Pencurian Sepeda Motor Di Kabupaten Bima. Pertama Bagaimana Pengaturan Praktik Penadahan Hasil Pencurian Sepeda Motor Di Kabupaten Bima?. Kedua Bagaimana Model Pelaksanaan Praktik Penadahan Hasil Pencurian Sepeda Motor Di Kabupaten Bima?

\section{B. METODE PENELITIAN}

Sebagai usaha untuk mendekati kesempurnaan di dalam penelitian ini, Penulis akan menggunakan jenis penelitian "Empiris" yaitu yang dileti pada awalnya adalah data skunder, untuk kemudian dilanjutkan dengan penelitian data primer lapangan, atau terhadap masyarakat. ${ }^{4}$ Penelitian hukum empiris adalah sebuah metode penelitian hukum yang berupaya untuk melihat hukum dalam artian yang nyata atau meneliti bekerjanya hukum di masyarakat. ${ }^{5}$ Tentunya dalam hal ini tentang Praktik Penadahan Hasil Pencurian Sepeda Motor Di Kabupaten Bima. Dalam penelitian ini, pendekatan penelitian yang di gunakan adalah sebagai berikut :

1. Pendekatan Perundang-Undangan (statute approach) Pendekatan yang dilakukan dengan cara menelaah dan mengkaji peraturan perundangundangan dan regulasi yang berkaitan dengan permasalahan Praktik Penadahan Hasil Pencurian Sepeda Motor Di Kabupaten Bima.

2. Pendekatan konseptual (conseptual approach) Pendekatan konseptual, yakni pendekatan yang dilakukan dengan mengkaji konsep-konsep, asas-

${ }^{4}$. Soejono Soekanto. 2014,Pengantar Penelitian Hukum, Jakarta, UI Pres, Hal : 52

5 . Bambang Waluyo, 2002 Penelitian Hukum Dalam Praktik, Jakarta, Sinar Grafika, Hal 15 asas hukum, prinsip-prinsip hukum serta pandangan dan doktrin/pendapat para ahli yang berkaitan dengan permasalahan Praktik Penadahan Hasil Pencurian Sepeda Motor Di Kabupaten Bima.

3. Pendekatan Sosiologis Pendekatan sosiologis, yaitu pendekatan yang mengetahui keberlakuan atau penerapan aturan-aturan hukum dengan kenyataan yang ada di tengahtengah masyarakat atau pendekatan masalah yang melihat secara langsung realita yang ada di lapangan mengenai Praktik Penadahan Hasil Pencurian Sepeda Motor Di Kabupaten Bima.

4. Pendekatan Kasus (case approach) Pendekatan kasus di lakukan dengan cara melakukan telaah terhadap kasuskasus yang berkaitan dengan isu yang di hadapi tentang kasus dalam Praktik Penadahan Hasil Pencurian Sepeda Motor Di Kabupaten Bima.

\section{PEMBAHASAN}

1. Pengaturan Praktik Penadahan Hasil

Pencurian Sepeda Motor Di

\section{Kabupaten Bima}

\section{a. Penadahan Dan Pencurian Sepeda Motor}

Dalam tindak pidana penadahan dan pencurian sepeda motor, sebenarnya dua perbuatan pidana yang dapat di pertanggungjawabkan secara pidana dengan ancaman pidana yang berbeda, sebab tindak pidana penadahan di atur dalam Pasal 480 Kitab Undang-Undang Hukum Pidana (KUHP) Ayat (1) dan (2) Dengan hukuman penjara selamalamanya empat tahun atau denda sebanyak-banyaknya Rp 900,000 dihukum. Karena sebagai sekongkol, barangsiapa yang membeli, menyewa, menerima tukar, menerima gadai, menerima sebagai hadiah, atau karena hendak 
mendapat untung, menjual, menukarkan, menggadaikan, membawa, menyimpan atau menyembunyikan sesuatu barang, yang diketahuinya atau yang patut disangkanya diperoleh karena kejahatan. kemudian barangsiapa yang mengambil keuntungan dari hasil sesuatu barang, yang diketahuinya atau yang patut harus disangkanya barang itu diperoleh karena kejahatan.

Sedangkan elemen penting Pasal 480 KUHP ini adalah terdakwa harus mengetahui atau patut dapat menyangka bahwa barang itu asal dari kejahatan. Di sini terdakwa tidak perlu tahu dengan pasti asal barang itu dari kejahatan apa (pencurian, penggelapan, penipuan, pemerasan, uang palsu atau lain-lain), akan tetapi sudah cukup apabila ia patut dapat menyangka (mengira, mencurigai) bahwa barang itu bukan barang terang.Untuk membuktikan elemen ini memang sukar, akan tetapi dalam prakteknya biasanya dapat dilihat dari keadaan atau cara dibelinya barang itu, misalnya dibeli dengan di bawah harga, dibeli pada waktu malam secara bersembunyi yang menurut ukuran di tempat itu memang mencurigakan.

Apabila kita melihat bekerjanya hukum pidana haruslah di memenuhi sebagai berikut :

1) Penggunaan hukum pidana harus memperhatikan tujuan pembangunan nasional yaitu mewujudkan masyarakat yang adil dan makmur meratamateril dan spiritual berdasarkan Pancasila. Maka hukum pidana harus bertugas dan bertujuan untuk menanggulangi kejahatan demi kesejahteraan dan pengayoman masyarakat.
2) Perbuatan yang diusahakan untuk dicegah atau di tanggulangi oleh hukum pidana adalah perbuatan yang tidak dikehendaki, yaitu perbuatan yang mendatangkan kerugian kepada masyarakat. Perbuatan yang tidak merugikan tidaklah boleh ditetapkan sebagai perbuatan yang tidak dikehendaki, meskipun tidak semua perbuatan yang merugikan perludicegah dengan menggunakan hukumpidana.

3) Usaha untuk mencegah suatu perbuatan dengan menggunakan saranahukum pidana dengan sanksi negatif berupa pidana, perlu di sertai perhitungan biaya yang akan dikeluarkan dan hasil yang diharapkan akandicapai (cost-benefit principle).

4) Penggunaan hukum pidana harus pula memperhatikan kapasitas dan kemampuan daya kerja dari badan-badan penegak hukum, jangan sampaikelampauan beban tugas (overbelasting) yang mana akan mengakibatkan efek dari peraturan itu akan menjadi berkurang. ${ }^{6}$

Dengan demikian hal ini sebenarnya sistem nilainya adalah jangan sembarangan membeli motor atau kendaraan murah yang tak dilengkapi surat-surat lengkap. Niat baik Anda untuk berhemat bisa berakibat fatal jika ternyata kendaraan bermotor yang Anda beli berasal dari hasil kejahatan. Tidak ada yang menjamin anda lolos dari jerat hukum. Polisi bisa saja

6 . Syafrudin. S. Hasibuan, 2004, Bunga Rampai Hukum Pidana dan Kriminologi :Menyambut 70 tahun Profesor H.M. Daud, Medan, Pustaka Bangsa Press, Hal 115 
menuduh Anda menadah barang hasil curian. Dan, ancaman empat tahun penjara menanti di depan mata.

Sedangkan tindak pidana pencurian di atur dalam Pasal 362 KUHP yang berbunyi Barangsiapa mengambil suatu barang, yang seluruhnya atau sebagian kepunyaan orang lain, dengan maksud untuk memilikinya secara melawan hukum, diancam karena pencurian dengan pidana penjara paling lama lima tahun atau denda sebanyak-banyaknya Rp 900.000.

Namun selain itu apabila tindakan seseorang memenuhi unsur-unsur pencurian di Pasal 362 KUHP maka orang tersebut dapat dikenakan ancaman pidana yang dimaksud. Unsur-unsur Barangsiapa mengambil suatu barang, yang seluruhnya atau sebagian kepunyaan orang lain dan Dengan maksud untuk memilikinya secara melawan hukum.Lebih lanjut mengenai pencurian juga tersebar dalam beberapa Pasal misalnya KUHP Pasal 363 ayat (1) Barangsiapa mengambil barang sesuatu, yang seluruhnya atau sebagian kepunyaan orang lain dengan maksud untuk dimiliki secara melawan hukum, di ancam karena pencurian, dengan pidana penjara paling lama lima tahun atau denda paling banyak enam puluh ribu rupiah"

Selanjutnya KUHP Pasal 365(1) Diancam dengan pidana penjara paling lama 9 (sembilan) tahun, pencurian yang didahului, disertai atau diikuti dengan kekerasan atau ancaman kekerasan, terhadap orang, dengan maksud untuk mempersiapkan atau mempermudah pencurian, atau dalam hal tertangkap tangan, untuk memungkinkan melarikan diri sendiri atau peserta lainnya, atau untuk tetap menguasai barang yang dicuri. (2) Diancam dengan pidana penjara paling lama 12 (dua belas) tahun.

Dalam pengamatan peneliti praktik penadahan hasil pencurian sepeda motor di Kabupaten Bima marak terjadi, hal ini sebenarnya disebabkan oleh kultur masyarakat bima yang tidak mau ambil repot dan wajah penegakan hukkum dalam berlalu lintas masih bisa di kompromi pada akhirnya membeli motor yang tidak lengkap, akibat tingginya permintaan masyarakat, maka membuat pencuri dapat mengkomunikasi barang hasil curianya untuk dapat di jual oleh pihak ketiga yang disebut penadah.

Pencurian kendaraan

bermotor merupakan kejahatan terhadap hartabenda yang tidak lazim terjadi dinegara-negara berkembang. Sebagaimana dikatehui kendaraan bermotor merupakan sarana transportasi dengan mobilitas yang tinggi. Seiring banyaknya kasus pencurian kendaraan bermotor, maka semakin banyak pulatindak pidana penadahan kendaraan bermotor hasil dari pencurian tersebut.

Di Indonesia pada saat ini masih marak tindak pidana kejahatan yang selalu saja terjadi, khususnya pada tindak pidana pencurian terhadap harta benda yang diatur pada Pasal 362 Kitab Undang-Undang Hukum Pidana. Di antara beberapa jenis kejahatan terhadap pencurian harta benda salah satunya ialah kejahatan pencurian kendaraan bermotor.

Dalam isu penelitian ini tentunya mengarah kepada pencurian sepeda motor dalam dua aspek tindak pidana penadahan dan pencurian yang di lakukan oleh setiap orang yang dapat memenuhi unsur tindak pidana yang dapat di pertanggungjawabkan secara pidana 
dalam prespektif hukum pidana Indonesia.

Sebab Tindak pidana penadahan disebut tindak pidana pemudahan yakni karenaperbuatan menadah telah mendorong orang lain untuk melakukan kejahatankejahatan yang mungkin saja tidak akan dilakukan, seandainya tidak ada orang yang bersedia menerima hasil kejahatannya. Dapat dikatakan menolong atau mempermudah kejahatan itu sekedar si pelaku kejahatan dapat mengharapkan bahwa barang yang telah dicuri, dirampas atau digelapkan atau diperoleh denganpenipuan, akan ditampung oleh seorang penadah dimana akan mempersulit pengusutan kejahatan yang bersangkutan.

b. Kepolisian Dalam

\section{Penanggulangan Praktik}

\section{Penadahan Sepeda Motor}

Meskipun informasi tentang kasus penadahan tersebut juga dapatditerima dari para saksi, yang menjadi saksi atas kasus penadahan adalah Polisiyang melakukan penangkapan terhadap curanmor dan pelaku penadahan itusendiri. Untuk kesaksian dari pelaku, berlaku split perkara, yaitu dimana pelakusebagai tersangka sekaligus sebagai saksi. Seorang penadah dapat menjadi saksiuntuk pencuri dan sebaliknya seorang pemain dapat menjadi saksi untukpenadah. Tetapi berkas perkara antara penadah dan pencurinya dipisah dalamberkas perkara yang berbeda, demikianlah yang di lakukan dalam pemberantasan praktik penadahan hasil pencurian sepeda motor di Kabupaten Bima. ${ }^{7}$

${ }^{7}$.Hasil Wawancara Dengan Bapak Mukhdar Selaku Kanit Intelkam Polsek Langgudu Kabupaten Bima, Pada Tanggal 10 Januari 2019 \begin{tabular}{lcr}
\multicolumn{1}{c}{ Penulis } & menganggap & bahwa \\
walaupun & usaha & untuk \\
memberantas & tindak & pidana
\end{tabular} penadahan sangatsulit dilakukan, namun setidaknya kepolisian sudah berusaha untuk mengatasi dan mencegah atau mengurangi terjadinya tindak pidana penadahan sepeda motor. Halini sebagai bukti adanya suatu usaha peningkatan pengawasan terhadap masyarakat terutama yang dilakukan oleh pihak kepolisian dalam melakukan penggerebekan terhadap pelaku tindak pidana, selain itu juga sangat diperlukan adanya partisipasi dari masyarakat untuk selalu memberikan informasi dalam rangka kerja sama untuk menciptakan keamanan serta ketertiban.

Salah satu kesulitan bagi kepolisian dalam penanggulangan penadahan di Kabupaten Bima, atas temuan kami selama ini adanya pihak lain yang terlibat dalam praktik penadahan hasil pencurian sepeda motor tersebut termasuk anggota kepolisian.

Polres Kabupaten Bima dalam mengungkap kasus tindak pidanapenadahan di Kabupaten Bima memiliki peran yang sangat penting misalnya adanya laporan kasus penadahan, setelah melakukan penyelidikan dan kalau memangterbukti telah terjadi tindak pidana penadahan maka pihak kepolisian Polres Kabupaten Bima melakukan penangkapan terhadap pihak-pihak terkait dengan tindakpidana.

Selain ini dalam pengamatan penulis ada juga faktor ekonomi Faktor ini sangat berpengaruh dalam hal timbulnya kejahatan (tindak pidana), sebab ekonomi yang berbeda atau tidak merata menimbulkan adanya suatu jurang pemisah antara golongan kaya dan golongan miskin yang hidup relatif 
menderita.Hal ini mengandung kebenaran walaupun tidak seluruhnya sebagai penyebab tindak pidana penadahan.

\section{Praktik Penadahan Hasil Pencurian}

\section{Sepeda Motor Di Kabupaten Bima}

a. Penadahan Hasil Pencurian Sepeda

Motor Di Kabupaten Bima

Dalam konsep teori bahwa tuhan mengawasi perilaku manusia secara langsung yang bermuara kepada konsep bahwa dalam menjalankan penegakan hukum ada struktur hukum yang di gambarkan dalam peraturan perundangundangan yang berlaku, praktik penadahan haruslah di awasi sebagai bentuk pencegahan penegak hukum agar meminimalisir terjadinya praktik penadahan oleh penadah tersebut.

Perbuatan penadah terbagi dua yakni (1) Yang menadah menerima dengan tangannya. Yakni membeli, menyewa, memakai, menerima gadai dan menerima sebagai hadiah, (2) Yang menadah melepaskan barang dari tangannya. Yakni menyewakan, menukarkan, menggadaikan, memberi sebagai hadiah, mengangkut dan menyembunyikan. Perbuatan ini harus ada unsur "dengan maksud hendak mendapat untung. ${ }^{8}$

Karena penadahan di anggap sebagai perbuatan pidana atau tindak pidana, harus memenuhi unsur, yaitu barangsiapa membeli, membeli, menyewa menukar, menerima sebagai gadai, menerima sebagai hadiah atau dengan pengharapan akan memperoleh keuntungan menjual, menyewakan,

8. Wawan Tunggul Alam, 2008 Hukum Bicara "Masalah Keluarga, Perdata, Pidana, Hukum Pidana dan Perdata (Jakarta: Bentara Cipta Prima, Hal 127 menukarkan, menggadaikan, mengangkut, menyimpan atau penyembunyikan sesuatu benda yang diketahuinya atau secara patut harus dapat diduganya, bahwa benda tersebut telah diperoleh karena kejahatan. ${ }^{9}$

Hidup manusia tidak terlepas dari masalah ekonomi, baik yang tinggal di perdesaan maupun di perkotaan. Karena tekanan ekonomi dan minimnya pendidikan, seseorang tanpa pekerjaan yang memadai akan sulit untuk menyabung hidupnya denganlayak. Maka cara yang paling mudah adalah dengan mencuri. Seiring dengan semakin banyaknya barang yang dicuri, maka semakin banyak pula barang yang dapat ditadah.

Sehingga Penggunaan hukum pidana dalam kehidupan masyarakat sebenarnya dilakukan dalam rangka untuk meningkatkan kesadaran hukum masyarakat, sehingga penting untuk ditanamkan pada masyarakat supaya didalamnya berkembang baik suatu sikap dan perasaan yang taat terhadap peraturan-peraturan, agar setiap orang menyadari dan menghargai hak serta kewajibannya masing-masing sebagai individu maupun sebagai anggota masyarakat.

Di Bagian Utara tepatnya di Kecamatan Wera-Ambalawi Kabupaten Bima Praktik penadahan terhadap hasil pencurian sepeda motor di Kabupaten Bima, berdasarkan hasil Wawancara dengan penadah sejak tahun 20092018 wilayah praktiknya di Kecamatan Wera-Ambalawi Kabupaten Bima dengan inisial B menggambarkan bahwa praktik penadahan itu sebetulnya tidak

${ }^{9}$. S.R. Sianturi, 1983, Tindak Pidana di KUHP Berikut Uraiannya, Jakarta, Alumni AHMPTHM, Hal 681 
hanya motor hasil pencurian di Wilayah Kota Bima, Dompu Dan Sumbawa, tetapi yang paling banyak adalah hasil pencurian dan penggelapan di luar Kota Bima yakni DKI Jakarta, ada parnert mereka di jakarta yang akan mengumpulkan motor tersebut, baru dikirim melalui mobil Fiso, jumlah motor yang dikirim antara 15-20 sekali kirim. ${ }^{10}$

Untuk melancarkan pengiriman motor bodong tersebut, mereka harus bekerja sama dengan pihak kepolisian, selain itu mereka siapkan motor yang lengkap suratsuratnya di yang akan disimpan paling belakang di mobil, sehingga menurut pengakuanya, polisi tidak mampu memeriksa semua motor yang ada mobil tersebut, atas penjelasan ini sebenarnya menggambarkan penegak hukum secara pribadi dan secara kelembagaan dapat di gunakan untuk melanggar hukum, maka wajah penegakan hukum pidana kita saat ini masing mencerminkan mafia-mafia dalam diri lembaga penegak hukum itu sendiri. Setelah sampai di Kabupaten Bima, mereka menampungkanya dalam satu tempat bahkan di simpan pada beberapa tempat supaya tidak dicurigai oleh pihak-pihak yang merasa dirugikan dari praktik penadahan tersebut.

Penadah

harus

memodifikasi motor hasil pencurian dari berbagai model pencurian tersebut, barulah dapat di tawarkan kepada masyarakat yang mengingikanya, biasanya sasaran mereka adalah masyarakat pedesaan yang biasanya motor tersebut hanya untuk keperluan

10 . Hasil Wawancara Dengan Bapak Budiman mantan Penadah di wilayah Kecamatan Wera-Ambalawi Kabupaten Bima Pada Tanggal 18 Januari Tahun 2019 bertani dan lainya. Modifikasi tersebut, bisa berupa mody motor, tetapi juga merubah nomor mesinya dan membuat STNK yang persis dengan aslinya (Palsu). ${ }^{11}$

Selain itu analisis penulis praktik penadahan seperti yang di gambarkan oleh penadah diatas sebetulnya menggabarkan bahwa memberikan kemudahan bagi seorang pencuri sepeda motor, sebab mereka tidak kesulitan untuk menjual motor hasil curiannya kepada masyarakat, tinggal dibawakan kepada penadah tersebut untuk di jualkan dengan keuntungan yang besar.

Sementara di wilayah Kecamatan Sanggar Kabupaten Bima, menurut pengakuan dari informan bahwa titik utama banyaknya motor hasil pencurian di tanpung pada Desa Kore dan Piong, di Desa Kore menurutnya terdapat beberapa tempat penampungan sebagai penadah sepeda motor hasil pencurian, model penadahan sebenarnya hampir sama seperti yang di gambarkan di atas, namun di Kecamatan Sanggar banyak motor hasil curian di wilayah Pulau Sumbawa seperti Sumbawa, Sumbawa Besar dan Kota Bima, meskipun banyak juga motor di luar Pulau Sumbawa yakni Pulau Lombok, modusnya adalah pencurian dan penggelapan. ${ }^{12}$

Masyarakat Kecamatan Sanggar Kabupaten Bima, baik sebagai pembeli sepeda motor hasil tanpungan maupun penanmpung motor membeli motor hasil curian di anggap sebagai suatu yang biasa,

11 . Hasil Wawancara Dengan Bapak Budiman mantan Penadah di wilayah Kecamatan Wera-Ambalawi Kabupaten Bima Pada Tanggal 18 Januari Tahun 2019

12. Hasil Wawancara Dengan Bapak Jayadi Penadah di wilayah Kecamatan Sanggar Kabupaten Bima Pada Tanggal 08 Januari Tahun 2019 
sebab aspek ekonomi membiasakan masyarakat di Kecamatan Sanggar untuk membeli motor hasil pencurian, karena di anggap murah dan memenuhi kebutuhan pekerjaan untuk bertani dan lain sebagainya, begitupun dengan penadah membeli motor dengan harga murah, kemudian menjual dengan harga sedikit mahal. Sementara harga motor yang di beli kepada penadah itu bergantung pada jenis motor yang di beli. ${ }^{13}$ Praktik penadahan di anggapnya sebagai sesuatu yang biasa saja, sedangkan jual beli motor hasil pencurian mayoritas akan di beli oleh masyarakat di sekitar lokasi, meskipun banyak juga masyarakat di luar Kecamatan Sanggar yang membeli motor hasil curian tersebut.

Pada wilayah Kabupaten Bima Selatan seperti Kecamatan Langgudu, sebenarnya cukup banyak masyarakat yang menggunakan motor hasil pencurian, yang mereka beli juga hasil penampungan oleh seorang penadah, dalam pengamatan penyusun masyarakat tidak mau ambil pusing untuk mengurus motor yang lengkap, sudah mahal dan harus juga membayar pajak setiap tahunya, bagi masyarakat langgudu, membeli motor hasil pencurian merupakan hal yang biasa di praktikan oleh masyarakat.

Sementara Berdasarkan

pengakuan informan dalam penelitian ini bahwa praktik penadahan terkadang untuk mendapatkan sepeda motor untuk di jual semuanya tidak secara langsung dari seorang pencuri sepeda motor tetapi juga akan di ambil dari seorang penadah lainya,

13. Hasil Wawancara Dengan Bapak Hamdi Masyarakat di wilayah Kecamatan Sanggar Kabupaten Bima Pada Tanggal 08 Januari Tahun 2019 meskipun mengambil langsung dari seorang pencuri juga paling banyak. ${ }^{14}$

Praktik penadahan hasil Pencurian kendaraan bermotor merupakan kejahatan terhadap harta benda yang tidak lazim terjadi di negara-negara berkembang. Sebagaimana dikatehui kendaraan bermotor merupakan sarana transportasi dengan mobilitas yang tinggi. Seiring banyaknya kasus pencurian kendaraan bermotor, maka semakin banyak pula tindak pidana penadahan kendaraan bermotor hasil dari pencurian.

Selain itu prkatik penadahan hampir sama juga seperti sebelumnya, namun di wilayah kecamatan langgudu ini sering banyak di tanpung dalam jumlah yang banyak, sebab masyarakat, sangat senang untuk melihat motormotor baru yang akan di tanpung, sehingga tidak herang, adanya pembeli motor kemudian menjual kembali pada seorang penadah untuk menggantikan dengan motor yang baru, meskipun kembali di jual dengan harga murah. Yang masuk di Kecamatan Langgudu paling banyak adalah motor hasil pencurian dan penggelapan yang berada di luar Daerah Bima. ${ }^{15}$

Berdasarkan temuan di lapangan bahwa di kecamatan Langgudu dalam praktik penadahan hasil pencurian sepeda motor Desa Laju dengan Rupe cukup biasa dilakukan, meskipun semua Desa lain juga selalu berada dalam jalur penadahan tersebut, juga adanya

14. Hasil Wawancara Dengan Bapak Syam Penadah di wilayah Kecamatan Langgudu Kabupaten Bima Pada Tanggal 23 Januari Tahun 2019

15 . Hasil Wawancara Dengan Bapak M yang meminta namanya tidak disebutkan dalam tulisan ini sebagai Penadah di wilayah Kecamatan Langgudu Kabupaten Bima Pada Tanggal 23 Januari Tahun 2019 
pihak yang melindungi praktik penadahan tersebut, seperti kepolisian semacam ada kerja sama dalam hal individu untuk dapat saling menguntukan antara pihak penadah dengan kepolisian. Apabila hal ini terus terjadi maka memang sangat sulit untuk dapat di berantas dengan tentang pemberantasan praktik penadahan hasil pencurian sepeda motor.

Perbuatan yang diusahakan untuk dicegah atau ditanggulangi oleh hukumpidana adalah perbuatan yang tidak dikehendaki, yaitu perbuatan yangmendatangkan kerugian kepada masyarakat. Perbuatan yang tidakmerugikan tidaklah boleh ditetapkan sebagai perbuatan yang tidakdikehendaki, meskipun tidak semua perbuatan yang merugikan perludicegah dengan menggunakan hukumpidana.

\section{PENUTUP}

Pengaturan tindak pidana penadahan hasil pencurian sepeda motor di Kabupaten Bima,sebenarnya terdapat tindak pidana yang berbeda yaitu tindak pidana penadahan dan tindak pidana pencurian, dalam tindak pidana penadahan di atur dalam Pasal 480 Kitab Undang-Undang Hukum Pidana (KUHP)sementara tindak pidana pencurian di atur dalam Pasal 362 Kitab Undang-Undang Hukum Pidana (KUHP). Dalam praktik penegakan hukum, pelaku tindak pidanapenadahan dapat di proses secara hukum tanpa mengetahui siapa pencuri motor begitupun sebaliknya, akan tetapi juga dapat berjalan bersama dalam proses hukum.

Praktik penadahan hasil pencurian sepeda motor di Kabupaten Bima, berdasarkan wilayah praktik penadahan hasil pencurian sepeda motor di Kecamatan Wera, Ambalawi, Sanggar dan Langgudu menunjukan adanya kesamaan dalam dalam menjalankan penadahan motor hasil pencurian, sementara sumber sepeda motor hasil pencurian dan penggelapan yang di kumpulkan oleh seorang penadah ada di wilayah Bima tetapi lebih banyak di Daerah Bima selain itu aspek ekonomi dan kebutuhan pokok masyarakat menjadi penyebabnya, sementara jual beli motor hasil pencurian di anggap sebagai hal yang biasa motor yang tidak mempunyai suratsuratnya.

Aparat penegak hukum dalam ini kepolisian juga sebenarnya sudah menunjukan adanya upaya yang dilakukan dalam pemberantasan tindak pidana penadahan hasil pencurian sepeda motor di Kabupaten Bima, tetapi jauh lebih bahaya adalah praktik penadahan ini berjalan atas kerja sama dengan oknum kepolsian.

\section{DAFTAR PUSTAKA}

\section{$\underline{\text { Buku }}$}

Bambang Waluyo, 2002 Penelitian Hukum Dalam Praktik, Jakarta, Sinar Grafika

Hajairin, 2017 Kriminologi Dalam Hukum Pidana, Yohyakarta, Suluh Media

Muhammad Ali, 2002, Kamus Lengkap Bahasa Indonesia Modern, Jakarta, Pustaka Aman

Redaksi Bhafana Fublishing, 2014,KUHP KUHAP, Jakarta: Bhafana Publishing

Soerjono Soekanto, 1988, Penanggulangan Pencurian Kendaraan Bermotor Suatu Tinjauan Kriminologi , Jakarta, Aksara

Soejono Soekanto. 2014,Pengantar Penelitian Hukum, Jakarta, UI Pres

Syafrudin. S. Hasibuan, 2004, Bunga Rampai Hukum Pidana dan Kriminologi :Menyambut 70 tahun Profesor H.M. Daud, Medan, Pustaka Bangsa Press 
S.R. Sianturi, 1983, Tindak Pidana di KUHP Berikut Uraiannya, Jakarta, Alumni AHM-PTHM

Wawan Tunggul Alam, 2008 Hukum Bicara "Masalah Keluarga, Perdata, Pidana, Hukum Pidana dan Perdata (Jakarta: Bentara Cipta Prima

\section{Hasil Wawancara}

Hasil Wawancara Dengan Bapak Mukhdar Selaku Kanit Intelkam Polsek Langgudu Kabupaten Bima, Pada Tanggal 10 Januari 2019

Hasil Wawancara Dengan Bapak Budiman mantan Penadah di wilayah Kecamatan Wera-Ambalawi Kabupaten Bima Pada Tanggal 18 Januari Tahun 2019

Hasil Wawancara Dengan Bapak Jayadi Penadah di wilayah Kecamatan Sanggar Kabupaten Bima Pada Tanggal 08 Januari Tahun 2019

Hasil Wawancara Dengan Bapak Hamdi Masyarakat di wilayah Kecamatan Sanggar Kabupaten Bima Pada Tanggal 08 Januari Tahun 2019

Hasil Wawancara Dengan Bapak Syam Penadah di wilayah Kecamatan Langgudu Kabupaten Bima Pada Tanggal 23 Januari Tahun 2019

Hasil Wawancara Dengan Bapak M yang meminta namanya tidak disebutkan dalam tulisan ini sebagai Penadah di wilayah Kecamatan Langgudu Kabupaten Bima Pada Tanggal 23 Januari Tahun 2019 